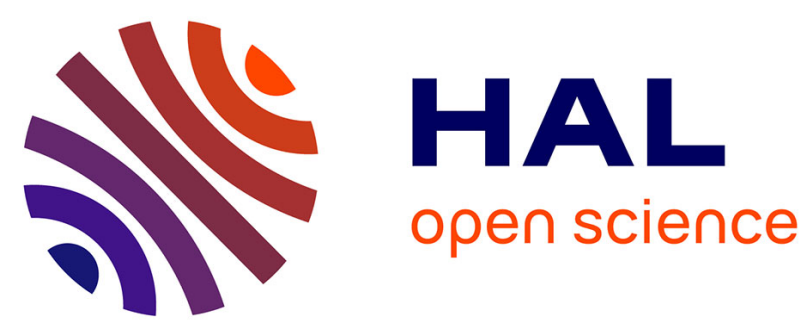

\title{
Bisphenol A diglycidyl ether (BADGE) migrating from packaging material 'disappears' in food: reaction with food components
}

Hauke Petersen, Andrea Biereichel, Kerstin Burseg, Thomas Joachim Simat, Hans Steinhart

\section{To cite this version:}

Hauke Petersen, Andrea Biereichel, Kerstin Burseg, Thomas Joachim Simat, Hans Steinhart. Bisphenol A diglycidyl ether (BADGE) migrating from packaging material 'disappears' in food: reaction with food components. Food Additives and Contaminants, 2008, 25 (07), pp.911-920. 10.1080/02652030701837399 . hal-00577444

HAL Id: hal-00577444

https://hal.science/hal-00577444

Submitted on 17 Mar 2011

HAL is a multi-disciplinary open access archive for the deposit and dissemination of scientific research documents, whether they are published or not. The documents may come from teaching and research institutions in France or abroad, or from public or private research centers.
L'archive ouverte pluridisciplinaire HAL, est destinée au dépôt et à la diffusion de documents scientifiques de niveau recherche, publiés ou non, émanant des établissements d'enseignement et de recherche français ou étrangers, des laboratoires publics ou privés. 


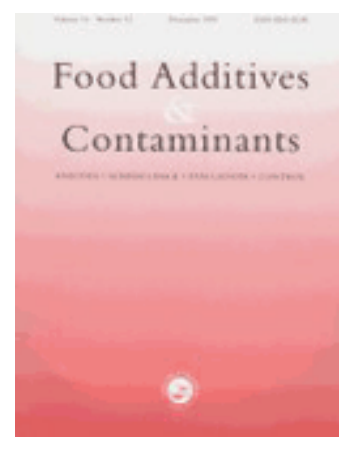

\section{Bisphenol A diglycidyl ether (BADGE) migrating from packaging material "disappears" in food: reaction with food components}

\begin{tabular}{|r|l|}
\hline Journal: & Food Additives and Contaminants \\
\hline Manuscript ID: & TFAC-2007-344.R1 \\
\hline Manuscript Type: & Original Research Paper \\
\hline Author: & 21-Nov-2007 \\
\hline & $\begin{array}{l}\text { Complete List of Authors: } \\
\text { Bundersen, Hauke; Central Institute of Medical Service German } \\
\text { Bureichel, Andrea; University of Hamburg, Institute of Biochemistry } \\
\text { Burseg, Kerstin; University of Hamburg, Institute of Biochemistry } \\
\text { and Food Chemistry } \\
\text { Simat, Thomas; Technical University of Dresden, Chair of Food } \\
\text { Science and Food and Skin Contact Materials } \\
\text { Steinhart, Hans; University of Hamburg, Institute of Biochemistry } \\
\text { and Food Chemistry }\end{array}$ \\
\hline Methods/Techniques: & Chromatographic analysis, Chromatography - HPLC \\
\hline Additives/Contaminants: & $\begin{array}{l}\text { Protein adducts, Food contact materials, Migration, Packaging - } \\
\text { BADGE }\end{array}$ \\
\hline Food Types: & \\
\hline &
\end{tabular}

\section{SCHOLARONE \\ Manuscripts}




\title{
Bisphenol A diglycidyl ether (BADGE) migrating from packaging material "disappears" in food: reaction with food components
}

\begin{abstract}
Bisphenol A diglycidyl ether (BADGE) is widely used as a monomer for coatings and adhesives for food contact applications. Previous publications indicate that, after migration from packaging into foodstuffs, BADGE undergoes various reactions with unidentified food components. In order to elucidate the fate of BADGE, losses were determined after incubation with different foodstuffs and food components. Food proteins were identified as the main reaction partner with BADGE. Adduct formation was found with nucleophilic side chains of amino acids. In vitro, cysteine exhibited significant activity. The previously reported occurrence of methylthio- derivatives of BADGE in foodstuffs were shown to originate from the reaction of BADGE with methionine. BADGE-methylthio derivatives can therefore be used as marker substances in foodstuffs for protein reactions with BADGE. The results reported here offer a new point of view on the evaluation of BADGE migration. The hydrolysis and hydrochlorination derivatives subject to European legislation make up only a fraction of the totally migrated BADGE, and a further concern is that the toxic or allergenic potential of the protein adducts are unknown.
\end{abstract}

Key words: Bisphenol A diglycidyl ether (BADGE), migration, food packaging, canned food, protein adducts

\section{Introduction}

Coated cans and light weight containers are frequently used for food packaging. In cans for food preserves, the coating is essential to prevent corrosion and migration of metals into food during production and storage. Light weight containers commonly consist of 
an aluminium foil, laminated with a polyolefin film. Depending on the processing conditions, the use of adhesives can be necessary to achieve a stable lamination. In can coatings, bisphenol A diglycidyl ether (BADGE) is used both as a monomer for epoxy resins and epoxy based polymers and as an additive for the elimination of surplus hydrochloric acid in the production of PVC organosols (Paseiro Losada et al. 1991, Biedermann et al. 1996). In adhesives for light weight containers, BADGE and its low molecular weight resins are used as reactive cross-linkers.

Due to its lipophilic character, BADGE tends to migrate from the coating into foodstuffs where various reactions take place during processing and storage, respectively. Most likely, the remaining epoxy groups are hydrolysed. Furthermore, hydrochlorination products may be formed in the presence of sodium chloride under slightly acidic conditions (Richard et al. 1999). In addition to these reactions, fast degradation of BADGE was observed in protein rich and carbohydrate rich foodstuffs (Richard et al. 1999). After spiking and heat treatment, only a small percentage of the spiked BADGE was detectable as known hydrolysis or hydrochlorination derivatives. The disappearance of BADGE amounted up to $98 \%$ of the spiked concentration. Because degradation did not depend on the concentration of BADGE in foodstuffs, it was assumed that reactions took place between BADGE and major food components (Richard et al. 1999) which had not been identified.

The technological properties of BADGE are defined by the reactivity of its epoxy groups. The same reactivity, however, leads to the formation of adducts with DNA (Vanhoutte et al. 1995). These adducts were identified as reaction products with primary amino groups of nucleosides. In addition, various reaction products are described for different epoxy containing substances, e.g. styrene oxide, with proteins (Hemminki 
1986, Phillips and Farmer 1994, Weston et al. 1989, Tannenbaum et al. 1993, Skipper et al. 1994, Brunmark et al. 1997).

Reaction of BADGE with proteins was already assumed by Richard et al. (1999), but no evidence was found to confirm this hypothesis. Thus, our investigations aimed at the elucidation of the reacting food components and the identification of binding sites for BADGE in order to evaluate the total migration of BADGE into foodstuffs.

\section{Materials and Methods}

Reference substances

Standards of BADGE, BADGE $\cdot \mathrm{HCl}, \mathrm{BADGE} \cdot 2 \mathrm{HCl}, \mathrm{BADGE} \cdot \mathrm{HCl} \cdot \mathrm{H}_{2} \mathrm{O}, \mathrm{BADGE} \cdot \mathrm{H}_{2} \mathrm{O}$ and BADGE $2 \mathrm{H}_{2} \mathrm{O}$ were purchased from Fluka, Switzerland. The internal standard Bisphenol A-di-3-hydroxypropyl ether (BADHPE) was synthesized as described elsewhere (Petersen et al. 2003).

\section{Amino acids and their $\mathrm{N}$-protected derivatives}

Experiments were carried out with Val and Phe representing both aliphatic and aromatic amino acids without nucleophilic side chains. To evaluate reactions other than with the $\square$-amino group, N-acetyl- derivatives were used for Val, Lys, Asp, Tyr, Cys and Met as well as t-Boc-derivatives for Phe, His, Arg, Asn and Ser, respectively. Acetyl or t-Bocderivatives were chosen due to their best availability.All amino acids used were from Fluka, Switzerland, or from Sigma Chemicals, Switzerland. 


\section{Model proteins}

Bovine serum albumin (BSA), haemoglobin and kappa-casein were purchased from Sigma Chemicals, Switzerland. Proteins of egg white, yolk, tuna, milk and wheat were isolated from foodstuffs as described below.

\section{Reagents}

Unless otherwise stated, reagents were of analytical grade.

Silica gel (Kieselgel 60, 230-400mesh, diameter 0.040-0.063mm) and kieselguhr were obtained from Merck, Germany. Methanol and acetonitrile were HPLC gradient grade (Merck, Germany). Purified water was obtained from a Millipore water purification system (Millipore, Italy) or by bidistillation (Heraeus, Germany). Solid phase extraction (SPE) was carried out using Chromabond ${ }^{\circledR}$ C18ec (Macherey \& Nagel, Germany). Ammonium formate buffer was prepared by mixing $100 \mathrm{~mL}$ of $50 \mathrm{mmol} / \mathrm{L}$ ammonia solution with $400 \mathrm{~mL}$ of water and adjusting the $\mathrm{pH}$ value to 3 with formic acid. This mixture was filled up to $1 \mathrm{~L}$ with water.

\section{Apparatus}

Sterilisation experiments were carried out using a SANOclav TKL-MCS-123 autoclave. Sample clean-up for analysis was performed using glass columns with PTFE stopcocks (300 x 30mm). HPLC analysis was done using a Hewlett Packard 1100 system with automatic degasser, binary pump, autosampler, column oven and fluorescence detector or mass selective detector with AP-ESI and APCI interface, respectively.

\section{Reaction with major components in foodstuffs}

Sunflower oil, tuna and peaches were chosen for these experiments because they exclusively contained fat, protein or carbohydrates as their major component. Tuna in 
oil was chosen in order to evaluate the influence of a fatty phase on the assumed reaction with proteins. To examine a broad range of concentrations, spiking solutions of BADGE and BADHPE in dioxane were used containing $0.04 \mathrm{mg} / \mathrm{mL}, 0.4 \mathrm{mg} / \mathrm{mL}, 4$ $\mathrm{mg} / \mathrm{mL}$ or $20 \mathrm{mg} / \mathrm{mL}$ of both substances. Spiking solution $(250 \mu \mathrm{L})$ were added to $10 \mathrm{~g}$ of homogenised foodstuff giving concentrations of $1,10,100$ or $500 \mathrm{mg} / \mathrm{kg}$. Recovery rates for BADGE and its known hydrolysis and hydrochlorination derivatives were determined immediately after spiking (control sample), after one day at ambient conditions or after $30 \mathrm{~min}$ sterilisation at $121^{\circ} \mathrm{C}$, respectively.

Sample preparation was performed as described previously (Petersen et al. 2003).

HPLC separation was carried out on Multospher ${ }^{\circledR} 1005 \mathrm{C} 18 \mathrm{ec} 250 \times 4 \mathrm{~mm}$ column. Gradient elution was performed with (A) $5 \mathrm{mM}$ ammonium formate in water $(\mathrm{pH} 3)$ and (B) acetonitrile/methanol (1:2) from $45 \% \mathrm{~A}$ to $16 \% \mathrm{~A}$ in $50 \mathrm{~min}$, followed by $10 \mathrm{~min}$ rinsing of the stationary phase $(10 \% \mathrm{~A})$ and 10 min equilibration to $45 \% \mathrm{~A}$ at $30^{\circ} \mathrm{C}$ and a flow rate of $0.8 \mathrm{~mL} / \mathrm{min}$. Detection was done by fluorescence $(275 / 305 \mathrm{~nm})$.

\section{Reaction in model solutions}

90mL aqueous solutions containing BSA $(\square=1 \mathrm{~g} / \mathrm{L})$ or glucose $(\square=100 \mathrm{~g} / \mathrm{L})$ were mixed with $10 \mathrm{~mL}$ standard solution ( $\square=10 \mathrm{mg} / \mathrm{L}$ BADGE und BADHPE in dioxane). Sample treatment and HPLC separation were carried out as described above.

\section{Isolation of proteins}

Egg proteins. $100 \mathrm{~g}$ of separated egg white were lyophilised after overnight storage at $80^{\circ} \mathrm{C}$. The remaining yolk was mixed with $100 \mathrm{~mL}$ acetone. After sedimentation, the supernatant was removed and the residue mixed and stirred with $100 \mathrm{~mL}$ diethyl ether. The procedure was repeated four times with $50 \mathrm{~mL}$ of acetone and diethyl ether. The fat 
free residue was suspended in $100 \mathrm{~mL}$ water and filtered through a Buchner funnel. The sludge cake was transferred into an Erlenmeyer flask and mixed with $100 \mathrm{~mL}$ water. After 30 min stirring, the filtration procedure was repeated and the residue was suspended in $50 \mathrm{~mL}$ water. The isolated yolk protein was lyophilised after overnight storage at $-80^{\circ} \mathrm{C}$ (modified procedure following Bernhisel-Broadbent (1989)).

Tuna proteins. The isolation of the proteins was carried out from $100 \mathrm{~g}$ of tuna following the procedure described for yolk.

Milk proteins. Low fat milk powder $(100 \mathrm{~g})$ were mixed with $100 \mathrm{~mL}$ acetone/water (50:50 v:v) and stirred for $30 \mathrm{~min}$. After sedimentation, the supernatant was removed and the procedure repeated seven times with $50 \mathrm{~mL}$ acetone/water $(50: 50 \mathrm{v}: \mathrm{v})$. The fat free and lactose free residue was filtered and treated as described for yolk.

Wheat albumin. 100g wheat flour was defatted corresponding to the method described for yolk. For the isolation of the water-soluble albumin fraction, the residue was suspended in $100 \mathrm{~mL}$ water and filtered through a Buchner funnel after vigorous stirring. This procedure was repeated twice. The combined filtrates were lyophilised after overnight storage at $-80^{\circ} \mathrm{C}$.

\section{Preparation of protein solutions}

BSA, haemoglobin, egg white protein, wheat albumin. $250 \mathrm{mg}$ of protein isolates were dissolved in $50 \mathrm{~mL}$ water.

Yolk proteins, casein, milk proteins, tuna proteins. $250 \mathrm{mg}$ of protein isolates were suspended in $25 \mathrm{~mL}$ water. After addition of $8 \mathrm{~mL}$ sodium hydroxide $(0.1 \mathrm{~mol} / \mathrm{L})$ the suspension was stirred for $10 \mathrm{~min}$. The resulting solution was adjusted to $\mathrm{pH} 7.4$ by addition of phosphoric acid (20\% v:v).and then filled up to $50 \mathrm{~mL}$ with water. After this step, tuna and yolk proteins were partly precipitated. The suspensions were used for the examinations. 


\section{Reaction with protein solutions}

$45 \mathrm{~mL}$ of the protein solutions or suspensions were mixed with $5 \mathrm{~mL}$ of standard solution ( $\square=100 \mathrm{mg} / \mathrm{L}$ BADGE $\cdot \mathrm{H}_{2} \mathrm{O}$ and BADHPE in dioxane) and shaken slightly. After 24 hours and seven days, respectively, of incubation at ambient conditions, $5 \mathrm{~mL}$ of the mixture were ground with $15 \mathrm{~g}$ kieselguhr, transferred into a glass column and eluted with $150 \mathrm{~mL}$ diethyl ether. The eluate was evaporated to dryness and re-dissolved in 0.5 $\mathrm{mL}$ acetonitrile and $4.5 \mathrm{ml}$ water. After dilution (1:10 with water), HPLC separation was carried out as described above.

Reaction with proteinogenic amino acids and their $N$-protected derivatives $10 \mathrm{mg}$ of each amino acid were dissolved in $9 \mathrm{~mL}$ water. By addition of phosphoric acid (1\% v:v) or sodium hydroxide $(1 \mathrm{M}), \mathrm{pH}$ values were adjusted to $\mathrm{pH} 3,5,7,9$ or 11 , respectively. Solutions were filled up to $10 \mathrm{~mL}$ with water $(\square=1 \mathrm{~g} / \mathrm{L}) .10 \mathrm{~mL}$ of amino acid solution were mixed with $1 \mathrm{~mL}$ of standard solution $\left(\square=100 \mathrm{mg} / \mathrm{L}\right.$ BADGE $\cdot \mathrm{H}_{2} \mathrm{O}$ and BADHPE in dioxane) and shaken slightly. Subsequently, mixtures were stored at ambient temperature and under exclusion of light. After 2 hours as well as after 1, 2, 3, 4 and 11 days, $200 \mu \mathrm{L}$ of each mixture were analysed. In case of N-Ac-Met, reaction was extended to 75 days.

For the identification of amino acid adducts, the mixture was analysed without dilution. The concentration of the reaction components was determined after dilution to $1 \mathrm{~mL}$ with water. One drop of formic acid was added to mixtures with alkaline $\mathrm{pH}$ prior to HPLC analysis. For HPLC analysis, gradient elution was modified using (A) 5mM ammonium formate in water ( $\mathrm{pH} \mathrm{3}$ ) and (B) acetonitrile from $70 \%$ A to $35 \%$ A in 30 minutes, followed by $5 \mathrm{~min}$ rinsing of the stationary phase $(10 \% \mathrm{~A})$ and $15 \mathrm{~min}$ equilibration with $70 \% \mathrm{~A}$ at $30^{\circ} \mathrm{C}$ and a flow rate of $0.8 \mathrm{~mL} / \mathrm{min}$. Detection was carried out with fluorescence $(275 / 305 \mathrm{~nm})$ or mass selective (AP-ESI positive, 100V 
fragmentor voltage, $4000 \mathrm{~V}$ capillary voltage, $40 \mathrm{psig}$ nebulizer pressure, $10 \mathrm{~L} / \mathrm{min}$ drying gas with $350^{\circ} \mathrm{C}$; scan $\mathrm{m} / \mathrm{z}$ 100-450 or SIM of characteristic ion tracks) detection.

\section{Methylthio derivatives in foodstuffs}

For spiking experiments, each $10 \mathrm{~g}$ of BADGE-free tuna and semolina pudding were spiked with $0.2 \mathrm{~mL}$ solution of BADGE $\cdot \mathrm{H}_{2} \mathrm{O}$ and BADHPE in dioxane ( $\square=500 \mathrm{mg} / \mathrm{L}$ ) and homogenised thoroughly. Subsequently, sterilisation was carried out for $30 \mathrm{~min}$ at $121^{\circ} \mathrm{C}$. The sterilised homogenates were prepared for analysis and analysed as described earlier (Petersen et al. 2003). For the elucidation of adduct formation in foodstuffs from BADGE containing packaging, 15 different foodstuffs in light weight containers from industrial production were prepared following the same procedure without spiking. Quantification of methylthio- adducts was carried out by calibration using BADGE as external standard following the assumption that the fluorescence activity of the methylthio- adducts and BADGE is similar. All analyses were carried out in triplicate.

\section{Synthesis of methylthio derivatives}

Solutions of $20 \mathrm{mg} \mathrm{N}$-Acetyl-methionine in $10 \mathrm{~mL}$ water were mixed with $1 \mathrm{~mL}$ solution of BADGE and BADHPE or BADGE·HCl and BADHPE in dioxane ( $\square=100 \mathrm{mg} / \mathrm{L}$ ) and stirred at ambient conditions for six days. Reaction mixtures were used for identification and characterisation of methylthio derivatives.

\section{Results}

\section{Reaction with major components in foodstuffs}

No decrease in BADGE concentrations were observed in sunflower oil in either the control sample or after incubation. Losses after sterilisation did not exceed the uncertainty of measurement of the control sample (Table 1). In spiked peaches the 
recovery after incubation was considerably lower than in the control sample. After one day at ambient temperature, a decrease of approximately $35 \%$ was observed without any formation of known hydrolysis or hydrochlorination derivatives. With higher BADGE concentrations recovery rates increased (Table1). After sterilisation, the loss of BADGE was nearly quantitative, partly under formation of BADGE $2 \mathrm{H}_{2} \mathrm{O}$. The total recoveries of BADGE and BADGE $2 \mathrm{H}_{2} \mathrm{O}$ were determined to be constantly at $70 \%$ (Table 1), corresponding to a disappearance of $30 \%$ of the initial amount.

After storage of tuna in oil at ambient conditions minor losses were detected, whereas after sterilisation recovery was only about $20 \%$. The degradation of BADGE did not lead to the formation of known derivatives under both sets of conditions. The lowest BADGE recoveries were found after incubation of tuna in brine. A considerable loss already occurred in the sample analysed immediately after spiking, whereas after one day at ambient temperature $80 \%$ of the spiked BADGE underwent reactions with food components. After sterilisation, only traces of BADGE were detectable (Table 1).

Table 1. Recovery of BADGE and detectable derivatives in spiked foodstuffs

\section{Reaction in model solutions}

The results shown above indicated that reactions most probably took place with food proteins. To test this hypothesis and furthermore to examine possible reactivity of carbohydrates, model solutions of major food components were spiked with BADGE. While immediately after spiking of BSA with a mass ratio of 1:900, recovery rates of $50 \%$ were found, adduct formation was quantitative after one day under ambient conditions. After sterilisation, hydrolysis to BADGE $2 \mathrm{H}_{2} \mathrm{O}$ was observed up to $30 \%$ of the spiked concentration. Adduct formation was measured as the difference between 
the initial amount of BADGE and the concentration of BADGE and its hydrolysis products after incubation. No adduct formation was found between BADGE and glucose as a model carbohydrate using a mass ratio of 1:90000 (corresponding to a molar ratio of 1:170000). The calculated decrease did not exceed the uncertainty of measurement. In the sterilised sample, BADGE was quantitatively hydrolysed giving BADGE $2 \mathrm{H}_{2} \mathrm{O}$ as the final product.

\section{Reaction with isolated proteins}

To investigate adduct formation, BADGE $\mathrm{H}_{2} \mathrm{O}(10 \mathrm{mg} / \mathrm{L})$ was reacted with different isolated proteins (each with $4500 \mathrm{mg} / \mathrm{L}$ ) at ambient temperature. The recovery rates of BADGE $\cdot \mathrm{H}_{2} \mathrm{O}$ were determined after 24 hours and after seven days, respectively. While the reaction with BSA led to adduct formation of more than $50 \%$, adduct formation with all other investigated proteins turned out to be considerably slower. With haemoglobin and tuna protein, adduct yields of $15 \%$ were determined after 24 hours, whereas for all other proteins adduct formation did not exceed $8 \%$ of the applied BADGE $\cdot \mathrm{H}_{2} \mathrm{O}$. Significantly different results were observed after seven days. Whereas the reaction with BSA was nearly quantitative (already after five days), the reaction with tuna protein gave highest values with $65 \%$, followed by about $30 \%$ for haemoglobin, kappa-casein, yolk and milk proteins. Reaction yields were considerably lower for proteins of egg white, while wheat protein showed no significant adduct formation (fig. 1).

Fig 1. Formation of BADGE $\cdot \mathrm{H}_{2} \mathrm{O}$ adducts after incubation with different protein solutions

These results support the assumed adduct formation between BADGE and food proteins. Therefore, the reactivity of different protein amino acids was examined. 


\section{Reactions with proteinogenic amino acids and their $N$-protected derivatives}

Besides their carboxylic and $\square$-amino groups, most protein amino acids possess functional side chains with different properties. BADGE, with its electrophilic oxirane rings, is subject to reactions with nucleophilic species. Consequently, reactions between BADGE and nucleophilic side chains were expected as well as the reaction with the $\square$ amino group. As described before, BADGE $\cdot \mathrm{H}_{2} \mathrm{O}$ was used instead of BADGE. Furthermore, a wide $\mathrm{pH}$ range was examined to simulate both acidic and alkaline foodstuffs. The mass ratio of $\mathrm{BADGE} \cdot \mathrm{H}_{2} \mathrm{O}$ to amino acids was $1: 100$ which corresponds to an approximate molar ratio of 1:130 for t-Boc-Arg up to 1:300 for Val. Adduct formation with free $\square$-amino groups was examined using Val and Phe as a model for N-terminal amino acids in polypeptide chains. Alongside, their N-protected derivatives were used to prove the lack of reaction with their carboxylic group or nonfunctional side chains.

Under alkaline conditions, adduct formation was detectable after two hours with both Val and Phe. In addition, hydrolysis to BADGE $2 \mathrm{H}_{2} \mathrm{O}$ was observed. Adduct concentration increased steadily with reaction time. The N-protected derivatives of Val and Phe did not exhibit any adduct formation neither at alkaline nor at neutral or acidic conditions. For the examination of reactions with functional side chains, N-protected amino acids were used to prevent $\square$-amino adduct formation.

At $\mathrm{pH} 11$, adduct formation was observed with the N-protected derivatives of Lys, His, Tyr, Met and Cys. Unlike the others, the reaction with t-Boc-His revealed two products, resulting from reactions with each of both the $\square$ and $\square$ nitrogen atoms of the imidazole ring. Outstanding reactivity was found for $\mathrm{N}$-Ac-Cys, showing quantitative 
transformation within two hours. Hydrolysis to BADGE $2 \mathrm{H}_{2} \mathrm{O}$, as observed in all other cases, was reduced to a minimum. Under neutral conditions, adduct formation was quantitative after one week, whereas of all other amino acids, only t-Boc-His and N-AcMet showed considerable reactivity (fig. 2).

Fig. 2 Kinetics of adduct formation of BADGE $\cdot \mathrm{H}_{2} \mathrm{O}$ with proteinogenic amino acids at ambient temperature; a. $\mathrm{pH} \mathrm{7,} \mathrm{b.} \mathrm{pH} 11$; conditions cf. experimentals

\section{Adduct formation of BADGE with $N$-acetyl-methionine}

The reaction of BADGE $\cdot \mathrm{H}_{2} \mathrm{O}$ with $\mathrm{N}$-Ac-Met (molar ratio of approx. 1:190) was different from all other amino acids. Adduct formation occurred independent of the $\mathrm{pH}$ conditions with similar reaction velocities. Furthermore, adduct formation took place in two steps with the occurrence and subsequent disappearance of an intermediate substance prior to the formation of the final reaction product. This reaction turned out to be very slow, reaching maximum concentration of the adduct after more than ten weeks (fig. 3).

The structures of the intermediate as well as of the final adduct were elucidated using HPLC-MSD. The addition product of N-Ac-Met and BADGE $\cdot \mathrm{H}_{2} \mathrm{O}$ is cleaved resulting in the final adduct methylthio- BADGE $\mathrm{H}_{2} \mathrm{O}\left(\mathrm{BADGE} \cdot \mathrm{H}_{2} \mathrm{O} \cdot \mathrm{SCH}_{3}\right)$. The described reaction of the intermediate methionine sulfonium adduct of BADGE to methylthioBADGE shows a similarity to the reaction from S-adenosylmethionine to 5'methylthioadenosine and homoserine catalysed by the adenosylmethionine hydrolase (EC 3.3.1.2) (Gessler et al. 1988).

Fig. 3 Reaction of $\mathrm{BADGE} \cdot \mathrm{H}_{2} \mathrm{O}$ with $\mathrm{N}$-Acetyl-methionine; ambient temperature; $\mathrm{pH}$ 11; conditions cf. experimentals 
Identical reactions were observed for adduct formation with BADGE and BADGE·HCl giving BADGE $\cdot \mathrm{SCH}_{3}, \mathrm{BADGE} \cdot 2 \mathrm{SCH}_{3}$ and $\mathrm{BADGE} \cdot \mathrm{HCl} \cdot \mathrm{SCH}_{3}$, respectively.

\section{Methylthio- derivatives in spiked foodstuffs}

To examine the formation of methylthio derivatives in foodstuffs, tuna was chosen because of the known high reactivity of its proteins. In addition, semolina pudding was taken to analyse formation with milk proteins. Both foodstuffs were analysed for the presence of BADGE and its derivatives prior to adding the spiking solution. In spiked tuna, BADGE $\cdot \mathrm{H}_{2} \mathrm{O}$ reacted quantitatively during sterilisation. Besides BADGE $2 \mathrm{H}_{2} \mathrm{O}$, BADGE $\cdot \mathrm{H}_{2} \mathrm{O} \cdot \mathrm{SCH}_{3}$ was detectable in considerable amounts (fig. 4).

Fig. 4 Chromatogram of spiked tuna after sterilisation. RP-HPLC/FLD, water (A): acetonitrile/methanol (1/2; B), 0 - 40 min 40 - $25 \%$ A, 5: BADGE $2 \mathrm{H}_{2} \mathrm{O}$; 8: BADHPE; 14: $\mathrm{BADGE} \cdot \mathrm{H}_{2} \mathrm{O} \cdot \mathrm{SCH}_{3}$; a: control sample, b: spiked with $10 \mathrm{mg} \mathrm{BADGE} \cdot \mathrm{H}_{2} \mathrm{O} / \mathrm{kg}$

BADGE $\cdot \mathrm{H}_{2} \mathrm{O} \cdot \mathrm{SCH}_{3}$ was also detectable after sterilisation of the spiked homogenate of semolina pudding. In both foods, about $15 \%$ of the spiked $\mathrm{BADGE} \cdot \mathrm{H}_{2} \mathrm{O}$ reacted under formation of $\mathrm{BADGE} \cdot \mathrm{H}_{2} \mathrm{O} \cdot \mathrm{SCH}_{3}$. The total recovery of BADGE derivatives, however, was significantly different in both foodstuffs, respectively (tab. 2).

Tab. 2 BADGE derivatives in tuna and semolina pudding both spiked with BADGE $\cdot \mathrm{H}_{2} \mathrm{O}$, after sterilisation

Methylthio- derivatives in foodstuffs from BADGE-containing packaging

As described above, reactions of BADGE and its oxirane containing derivatives with methionine resulted in the formation of the corresponding methylthio derivatives. Those 
were used as qualitative standards for the detection in foodstuffs originally sterilised in BADGE-containing packaging. All foods which were examined were packed and sterilised in light weight packaging made of a polyolefin film laminated to aluminium foil by deep drawing containing epoxy adhesives. Besides hydrolysis and hydrochlorination derivatives of BADGE, in most cases methylthio- derivatives were detectable (tab. 3). The highest percentage (up to $60 \%$ ) of methylthio- derivatives within all detectable BADGE derivatives was observed in foodstuffs with a protein share mainly consisting of milk proteins.

Table. 3 Regulated and methylthio derivatives of BADGE in foodstuffs

For a semolina pudding sample, analyses were repeated after two years in order to elucidate the formation of methylthio- derivatives during storage under ambient conditions. This was possible because of the originally high proportion of oxirane containing BADGE derivatives (fig.5).

Fig. 5 BADGE derivatives in semolina pudding from BADGE containing packaging RP-HPLC/FLD, water (A) : acetonitrile/methanol (1/2; B), 0-40 min $40-25 \% \mathrm{~A}, 1$ : BADGE; 2: BADGE·HCl; 3: BADGE-2HCl; 4: BADGE $\cdot \mathrm{H}_{2} \mathrm{O} ; 5$ : $\mathrm{BADGE} \cdot 2 \mathrm{H}_{2} \mathrm{O} ; 6$ : BADGE $\cdot \mathrm{HCl} \cdot \mathrm{H}_{2} \mathrm{O} ; 8$ : BADHPE; 14: BADGE $\cdot \mathrm{H}_{2} \mathrm{O} \cdot \mathrm{SCH}_{3} ; 15: \mathrm{BADGE} \cdot \mathrm{HCl} \cdot \mathrm{SCH}_{3} ; 16$ : BADGE $2 \mathrm{SCH}_{3}$ a: initial analysis, b: analysis after storage

During storage, oxirane containing BADGE derivatives were subject to reactions with food proteins. The loss of $0.65 \mathrm{mg} / \mathrm{kg}$ BADGE derivatives with an oxirane moiety gave an increase of $0.12 \mathrm{mg} / \mathrm{kg}$ (which is approximately $18 \%$ ) of methylthio derivatives. Concentrations of BADGE derivatives without reactive epoxy groups did not change significantly within two years (Table. 4). 
Table 4 BADGE derivatives in semolina pudding; epoxy containing derivatives in italics

\section{Discussion}

The results reported here confirm the findings of Richard et al. (1999) who proposed the reaction of epoxy groups with a major component of foodstuffs. Moreover, it was possible to identify food proteins as the reactive component. The lack of reactivity of triacylglycerides caused the difference between tuna in oil or in brine. Due to its lipophilic properties, BADGE is mainly found in the fatty phase and thus prevented from reaction with food proteins. Since no reaction was observed between BADGE and glucose, it is assumed that the conversion of BADGE in peaches results from the reaction with smaller amounts of proteins as minor components of peaches (protein content of peaches: $0.8 \%$, giving BADGE to protein mass ratios between 1:8000 and $1: 16$ in the experiments).

The adduct formation of different isolated food proteins with BADGE $\cdot \mathrm{H}_{2} \mathrm{O}$ varied widely. Ease of reaction was outstanding for BSA, whereas with wheat protein, BADGE $\cdot \mathrm{H}_{2} \mathrm{O}$ reactions giving unknown derivatives did not exceed measurement uncertainty. Reactions with food proteins were already expected by Richard et al. (1999). However, they did not observe any fluorescent adducts after hydrolysis with concentrated $\mathrm{HCl}$. Our results indicate that hydrolysis using hydrochloric acid leads to chlorination of the aromatic system of BADGE. The resulting derivatives do not possess any fluorescence activity. 
Subsequently, our investigations focused mainly on the identification of a reactive moiety in amino acids for the epoxy group of BADGE derivatives. As described above, the electrophilic properties of epoxy groups demand for nucleophilic structures. Furthermore, BADGE $\cdot \mathrm{H}_{2} \mathrm{O}$ was chosen instead of BADGE due to the fact that only one oxirane ring is available for adduct formation. Adduct formation was observed for the side chains of $\mathrm{N}$-protected derivatives of Cys, Tyr, Lys, His and Met. Obviously, nucleophilic properties of other proteinogenic amino acids were not sufficient to induce a reaction with BADGE. Especially at alkaline $\mathrm{pH}$ values, enhanced nucleophilic properties of thiols and aromatic hydroxy groups were expected due to the formation of thiolates and phenolates, respectively. Under physiological conditions, only N-Ac-Cys showed considerable conversion with BADGE $\cdot \mathrm{H}_{2} \mathrm{O}$. This confirms the results of Hemminki (1986), who described the particular readiness of Cys for reactions with styrene oxide. BADGE $\cdot \mathrm{H}_{2} \mathrm{O}$-His adducts have already been identified after the reaction of BADGE $\cdot \mathrm{H}_{2} \mathrm{O}$ and BSA and subsequent enzymatic hydrolysis (Petersen et al., 2001). Whereas Cys and His form stable adducts with oxiranes, the reaction with Met under identical conditions slowly leads to the formation of methylthio derivatives after cleavage from intermediate products.

The formation of BADGE methylthio derivatives in food was first reported by Richard et al. (1999) who described their occurrence in spiked tuna. However, they were not able to prove the proposed reaction between BADGE and Met because their attempts to synthesise these derivatives did not lead to success. Considering the very slow reaction leading to a maximum concentration of methylthio derivatives after several weeks, it is assumed that the reaction was cut off too early. Our results provide proof that BADGE methylthio- derivatives are formed from food proteins under spontaneous cleavage from an intermediate product with transfer of the methylthio- group from Met to BADGE 
similar to the enzyme catalysed reaction from ATP and Met via the sulfonium salt Sadenosylmethionine finally to 5'-methylthioadenosine and homoserine (Gessler et al. 1988).

The occurrence of methylthio derivatives in spiked foodstuffs gave hints for the possibility to use those substances as markers for BADGE reactions with food proteins. After having proved the formation of $\mathrm{BADGE} \cdot \mathrm{H}_{2} \mathrm{O} \cdot \mathrm{SCH}_{3}$ from $\mathrm{BADGE} \cdot \mathrm{H}_{2} \mathrm{O}$ and $\mathrm{N}-$ Ac-Met as well as from BADGE $\cdot \mathrm{H}_{2} \mathrm{O}$ and protein bound Met in tuna und semolina pudding the significance of this reaction was revealed for industrially produced foodstuffs. Therefore, all possible reaction products of BADGE and its derivatives with Met have been synthesized as qualitative standards by the reaction of BADGE and BADGE·HCl with $\mathrm{N}$-Ac-Met. Characterisation was carried out by their specific fragment pattern in HPLC-MSD analysis. Methylthio derivatives were found in most of the analysed foodstuffs with highest yields in those containing high proportions of milk proteins. This was to be expected considering the results of the isolated proteins.

As observed in semolina pudding, the storage over two years led to a significant change in the contamination pattern. While BADGE derivatives without epoxy groups were determined with constant concentrations, those with a reactive oxirane ring decreased to traces with simultaneous increase of methylthio- derivatives. This reaction, however, covered only a part of the decrease while reactions leading to protein-bound adducts may be considered predominant.

These results provide proof for the reaction of BADGE with food proteins as major food components during food processing and storage, while migration of BADGE and the formation of hydrolysis and hydrochlorination derivatives seems to occur mainly 
during the sterilisation process (tab. 3). Thus, it is possible to use methylthio adducts of BADGE and its epoxy containing derivatives as markers for the reaction of BADGE with food proteins. The decrease of the total amount of detectable BADGE derivatives is attributed to the reaction with other nucleophilic structures of proteins, especially with the thiol group of Cys.

The reaction of BADGE with proteins offers a new view on BADGE migration into foodstuffs. Current legal limits for BADGE (European Commission 2005) focus on BADGE and its hydrolysis and hydrochlorination derivatives, not taking into consideration the formation of protein adducts. As shown in tab. 2, in processed cheese methylthio adducts gave $60 \%$ of the detected BADGE derivatives. Considering the hypothesis that protein bound Met is only one of several possible binding sites for BADGE, it becomes obvious that the current legal limits only focus on parts of the actual contamination under certain circumstances. The toxicological relevance and the allergenic potential of protein adducts have not yet been investigated. The allergenic effects of BADGE as described by Kanerva et al. (1991) might well be attributed to the formation of adducts with skin proteins.

Proof is till needed to establish whether consideration of the legally regulated derivatives alone leads to a proper consideration of the toxicology of migrating BADGE derivatives. If this is not the case, the legal limitations have to be fundamentally reviewed.

\section{Acknowledgements}

The investigations were promoted by the Federal German Ministry of Defence (InSan I 1098-V-7501). 


\section{References}

Bernhisel-Broadbent K. 1989. Cross-allergenecity in the legume botanical family in children with hypersensitivity. Journal of Allergy and Clinical Immunology $83: 435-440$

Biedermann M, Grob K, Bronz M, Curcio R, Huber M, Lopez-Fabal F. 1996. Bisphenol-A-Diglycidyl Ether (BADGE) in Edible-Oil-Containing Canned Foods: Determination by LC-LC-Fluorescence Detection. Mitteilungen aus dem Gebiete der Lebensmitteluntersuchung und Hygiene 87:547-558

Brunmark P, Harriman S, Skipper PL, Wishnok JS, Amin S, Tannenbaum SR. 1997. Identification of Subdomain IB in Human Serum Albumin as a Major Binding Site for the Polycyclic Aromatic Hydrocarbon Epoxides. Chemical Research in Toxicology 10:880-886

European Commission. 2005. Commission Regulation (EC) No 1895/2005 of 18 November 2005 on the restriction of use of certain epoxy derivatives in materials and articles intended to come into contact with food. Official Journal of the European Union L 302/28

Gessler NN, Bezzubov AA, Bach AN. 1988. Study of the activity of Smethylmethionine sulfonium salt hydrolyse in plant and animal tissues. Prikladnaya Biokhimiya i Mikrobiologiya 24:240-246.

Hemminki K. 1986. Binding of Styrene Oxide to Amino Acids, Human Serum Proteins and Hemoglobin. Archives of Toxicology 9:286-290 
Kanerva L, Jolanki R, Tupasela O, Halmepuro L, Keskinen H, Estlander T. 1991. Immediate and delayed allergy from epoxy resins based on diglycidyl ether of Bisphenol A. Scandinavian Journal of Work, Environment \& Health 17:208-215

Paseiro Losada P, López Mahía P, Vázquez Odériz L, Simal Lozano J. 1991. Sensitive and Rapid Reversed-Phase Liquid Chromatography-Fluorescence Method for Determining Bisphenol A Diglycidyl Ether in Aqueous-Based Food Simulants. Journal of AOAC International 74:925-928

Petersen H, Burseg K, Simat TJ. 2001. Entsorgt eine Kontaminante sich selbst? BADGE und die Reaktion mit Lebensmitteln. Lebensmittelchemie 55:154-155

Petersen H, Schaefer A, Buckow CA, Simat TJ, Steinhart H. 2003. Determination of bisphenol A diglycidyl ether (BADGE) and its derivatives in food: identification and quantification by internal standard. European Food Research and Technology 216:355-364

Phillips DH, Farmer PB. 1994. Evidence for DNA and Protein Binding by Styrene and Styrene Oxide. Critical Reviews in Toxicology. 24:35-46

Richard N, Biedermann M, Grob K. 1999. Reaction of Bisphenol-A-Diglycidyl Ether (BADGE) from Can Coatings with Food Components. Mitteilungen aus dem Gebiete der Lebensmitteluntersuchung und Hygiene 90:532-545

Skipper PL, Peng X, Soohoo CK, Tannenbaum SR. 1994. Protein Adducts As Biomarkers Of Human Carcinogen Exposure. Drug Metabolism Reviews 26:111-124

Tannenbaum SR, Skipper PL, Wishnok JS, Stillwell WG, Day BW, Taghizadeh K. 1993. Characterization of Various Classes of Protein Adducts. Environmental Health Perspectives 99:51-55 
Vanhoutte K, Joos P, Lemière F, van Dongen W, Esmans EL. 1995. Thermospray Liquid Chromatography - Mass Spectrometry of the DNA Adducts Formed between 2'-Deoxy-nucleosides and Bisphenol A Diglycidyl Ether. Journal of Mass Spectrometry 30:1453-1461

Weston A, Rowe ML, Manchester DK, Farmer PB, Mann DL, Harris CC. 1989. Fluorescence and mass spectral evidence for the formation of benzo[a]pyrene anti-diol-epoxide-DNA and -hemoglobin adducts in humans. Carcinogenesis $10: 251-257$ 


\section{$\underline{\text { Figure captions }}$}

Fig. 1 Formation of BADGE $\cdot \mathrm{H}_{2} \mathrm{O}$ adducts after incubation with different protein solutions

Fig. 2 Kinetics of adduct formation of BADGE $\cdot \mathrm{H}_{2} \mathrm{O}$ with proteinogenic amino acids at ambient temperature; a. $\mathrm{pH} \mathrm{7,} \mathrm{b.} \mathrm{pH} \mathrm{11;} \mathrm{conditions} \mathrm{cf.} \mathrm{experimentals}$

Fig. 3 Reaction of $\mathrm{BADGE} \cdot \mathrm{H}_{2} \mathrm{O}$ with N-Acetyl-methionine; ambient temperature; $\mathrm{pH} 11$; conditions cf. experimentals

Fig. 4 Chromatogram of tuna after sterilisation

RP-HPLC/FLD, water (A) : acetonitrile/methanol (1/2; B), 0 - 40 min $40-25 \%$
A, 5:
BADGE $\cdot \mathrm{H}_{2} \mathrm{O}$;
8 :
BADHPE;

14: $\mathrm{BADGE} \cdot \mathrm{H}_{2} \mathrm{O} \cdot \mathrm{SCH}_{3}$; a: control sample, b: spiked

Fig. 5 BADGE derivatives in semolina pudding from BADGE containing packagings

RP-HPLC/FLD, water (A) : acetonitrile/methanol (1/2; B), 0 - 40 min $40-25 \%$
$\mathrm{A}$,
$1:$
BADGE;
2:
BADGE.HCl; 3: BADGE-2HCl; 4: BADGE $\cdot \mathrm{H}_{2} \mathrm{O} ; 5$ : BADGE $2 \mathrm{H}_{2} \mathrm{O} ; 6$ : BADGE $\cdot \mathrm{HCl} \cdot \mathrm{H}_{2} \mathrm{O} ; 8$ : BADHPE; 14:

$\mathrm{BADGE} \cdot \mathrm{H}_{2} \mathrm{O} \cdot \mathrm{SCH}_{3}$; 15: $\mathrm{BADGE} \cdot \mathrm{HCl} \cdot \mathrm{SCH}_{3} ; 16: \mathrm{BADGE} \cdot 2 \mathrm{SCH}_{3}$ a: initial analysis, b: analysis after storage 
Tab. 1 Recovery of BADGE and detectable derivatives in spiked foodstuffs

\begin{tabular}{|c|c|c|c|c|}
\hline Foodstuff & $\begin{array}{c}\text { Spiked concentration } \\
{[\mathrm{mg} / \mathrm{kg}]}\end{array}$ & Treatment & $\begin{array}{c}\text { BADGE recovery } \\
{[\%]}\end{array}$ & $\begin{array}{c}\text { Detectable derivatives } \\
{[\%]}\end{array}$ \\
\hline \multirow{2}{*}{ Sunflower oil } & $1-500$ & $24 \mathrm{~h}$ ambient & $93-97$ & n.d. $(<1)$ \\
\hline & $1-500$ & $30 \min 120^{\circ} \mathrm{C}$ & $90-93$ & n.d. $(<1)$ \\
\hline \multirow{8}{*}{ Peach } & 1 & $24 \mathrm{~h}$ ambient & 65 & n.d. $(<1)$ \\
\hline & 10 & & 67 & n.d. $(<1)$ \\
\hline & 100 & & 82 & n.d. $(<1)$ \\
\hline & 500 & & 97 & n.d. $(<1)$ \\
\hline & 1 & $30 \min 120^{\circ} \mathrm{C}$ & 2 & 67 \\
\hline & 10 & & 1 & 72 \\
\hline & 100 & & 1 & 69 \\
\hline & 500 & & 3 & 72 \\
\hline \multirow{8}{*}{ Tuna in oil } & 1 & $24 \mathrm{~h}$ ambient & 70 & n.d. $(<1)$ \\
\hline & 10 & & 74 & n.d. $(<1)$ \\
\hline & 100 & & 80 & n.d. $(<1)$ \\
\hline & 500 & & 93 & n.d. $(<1)$ \\
\hline & 1 & $30 \min 120^{\circ} \mathrm{C}$ & 16 & n.d. $(<1)$ \\
\hline & 10 & & 15 & n.d. $(<1)$ \\
\hline & 100 & & 25 & n.d. $(<1)$ \\
\hline & 500 & & 25 & n.d. $(<1)$ \\
\hline \multirow{8}{*}{ Tuna in brine } & 1 & $24 \mathrm{~h}$ ambient & 16 & n.d. $(<1)$ \\
\hline & 10 & & 15 & n.d. $(<1)$ \\
\hline & 100 & & 17 & n.d. $(<1)$ \\
\hline & 500 & 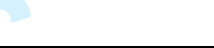 & 21 & n.d. $(<1)$ \\
\hline & 1 & $30 \min 120^{\circ} \mathrm{C}$ & 3 & n.d. $(<1)$ \\
\hline & 10 & & 1 & n.d. $(<1)$ \\
\hline & 100 & & 1 & n.d. $(<1)$ \\
\hline & 500 & & 1 & n.d. $(<1)$ \\
\hline
\end{tabular}


Tab. 2 BADGE derivatives in tuna and semolina pudding both spiked with BADGE $\mathrm{H}_{2} \mathrm{O}$, after sterilisation

\begin{tabular}{|l|c|c|}
\hline BADGE derivative & $\begin{array}{c}\text { Tuna } \\
{[\%]}\end{array}$ & $\begin{array}{c}\text { Semolina pudding } \\
{[\%]}\end{array}$ \\
\hline BADGE $2 \mathrm{H}_{2} \mathrm{O}$ & 18 & 52 \\
\hline BADGE $\cdot \mathrm{H}_{2} \mathrm{O}$ & --- & -- \\
\hline BADGE $\mathrm{H}_{2} \mathrm{O} \cdot \mathrm{HCl}$ & --- & 12 \\
\hline BADGE $\cdot \mathrm{H}_{2} \mathrm{O} \cdot \mathrm{SCH}_{3}$ & 17 & 15 \\
\hline 'Disappeared' $\mathrm{BADGE} \cdot \mathrm{H}_{2} \mathrm{O}$ & 65 & 21 \\
\hline
\end{tabular}


Tab. 3 Regulated and methylthio derivatives of BADGE in foodstuffs

\begin{tabular}{|c|c|c|c|}
\hline Foodstuff & $\begin{array}{c}\text { Sum of regulated } \\
\text { BADGE derivatives } \\
{[\mathrm{mg} / \mathrm{kg}]}\end{array}$ & $\begin{array}{l}\text { Sum of methylthio } \\
\text { derivatives [mg/kg] }\end{array}$ & $\begin{array}{l}\text { Sum of detectable } \\
\text { derivatives }[\mathrm{mg} / \mathrm{kg}]\end{array}$ \\
\hline Liver sausage & 1.15 & n.d. $(<0.02)$ & 1.15 \\
\hline Sliced cold meat 1 & 1.37 & 0.15 & 1.52 \\
\hline Sliced cold meat 2 & 0.61 & n.d. $(<0.02)$ & 0.61 \\
\hline Processed cheese & 0.45 & 0.68 & 1.13 \\
\hline Processed cheese with pepper & 0.31 & 0.44 & 0.75 \\
\hline Pork with lard & 1.38 & 0.19 & 1.57 \\
\hline Semolina pudding & 1.18 & 0.47 & 1.65 \\
\hline Mixed fruits & 1.83 & n.d. $(<0.02)$ & 1.83 \\
\hline Sweet rice dessert with fruits & 0.59 & n.d. $(<0.02)$ & 0.59 \\
\hline Hamburger with tomato sauce & 5.36 & 0.14 & 5.50 \\
\hline Lentil stew & 3.42 & 0.14 & 3.56 \\
\hline Vegetable pan & 3.72 & 0.18 & 3.90 \\
\hline Noodles with meat and sauce & 5.97 & 0.90 & 6.87 \\
\hline Cevapcici & 2.41 & n.d. $(<0.02)$ & 2.41 \\
\hline Goulash with potatoes & 2.66 & n.d. $(<0.02)$ & 2.66 \\
\hline
\end{tabular}


Tab. 4 BADGE derivatives in semolina pudding and storage time; epoxy containing derivatives in italics

\begin{tabular}{|c|c|c|}
\hline BADGE derivative & Concentration [mg/kg] 1999 & Concentration $[\mathrm{mg} / \mathrm{kg}] 2001$ \\
\hline $\mathrm{BADGE} \cdot 2 \mathrm{H}_{2} \mathrm{O}$ & 0.37 & 0.47 \\
\hline $\mathrm{BADGE} \cdot \mathrm{H}_{2} \mathrm{O}$ & 0.03 & n.d. $(<0.02)$ \\
\hline $\mathrm{BADGE} \cdot \mathrm{H}_{2} \mathrm{O} \cdot \mathrm{HCl}$ & 0.51 & 0.61 \\
\hline $\mathrm{BADGE} \cdot \mathrm{H}_{2} \mathrm{O} \cdot \mathrm{SCH}_{3}$ & 0.18 & 0.26 \\
\hline$B A D G E$ & 0.54 & 0.03 \\
\hline$B A D G E \cdot H C l$ & 0.11 & n.d. $(<0.02)$ \\
\hline $\mathrm{BADGE} \cdot 2 \mathrm{HCl}$ & 0.27 & 0.27 \\
\hline $\mathrm{BADGE} \cdot \mathrm{HCl} \cdot \mathrm{SCH}_{3}$ & 0.11 & 0.13 \\
\hline BADGE. $\mathrm{SCH}_{3}$ & n.d. $(<0.02)$ & n.d. $(<0.02)$ \\
\hline $\mathrm{BADGE} \cdot 2 \mathrm{SCH}_{3}$ & 0.06 & 0.08 \\
\hline
\end{tabular}




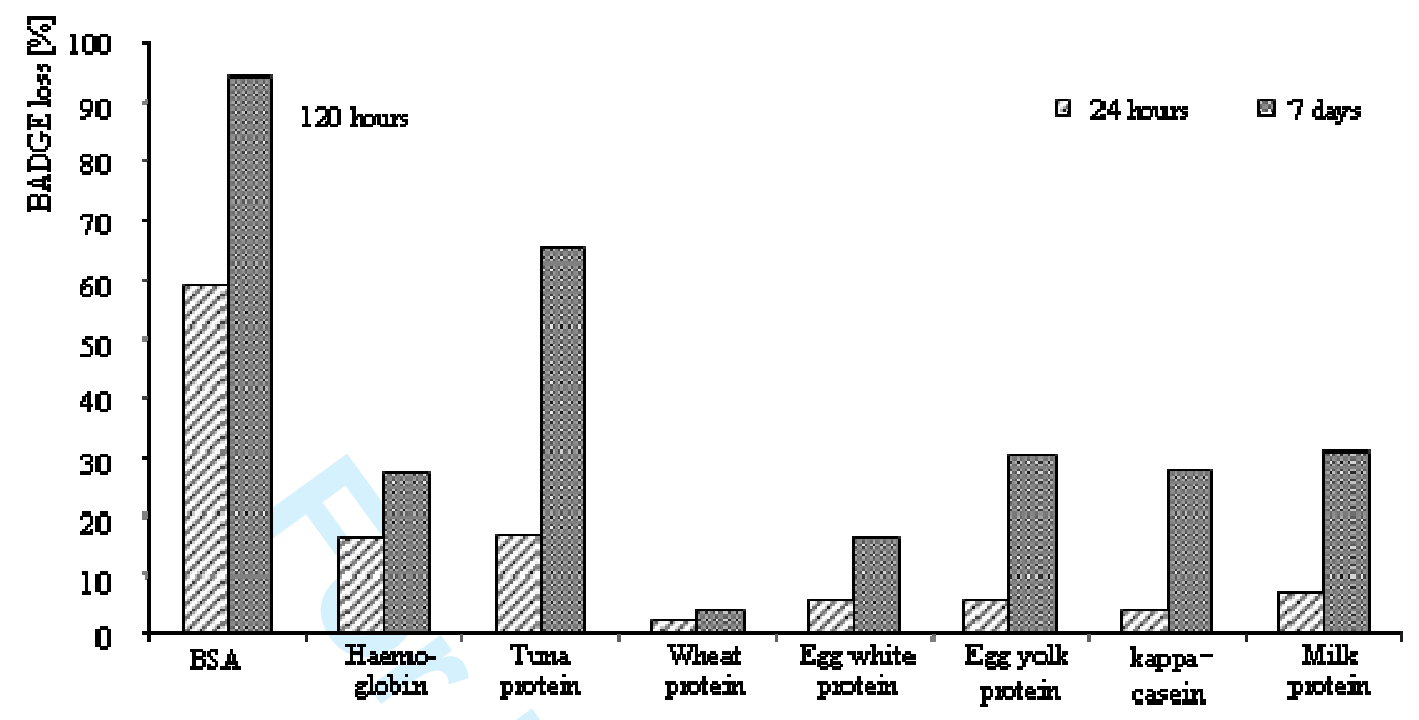

Fig. 1 Formation of BADGE $\cdot \mathrm{H}_{2} \mathrm{O}$ adducts after incubation with different protein solutions 

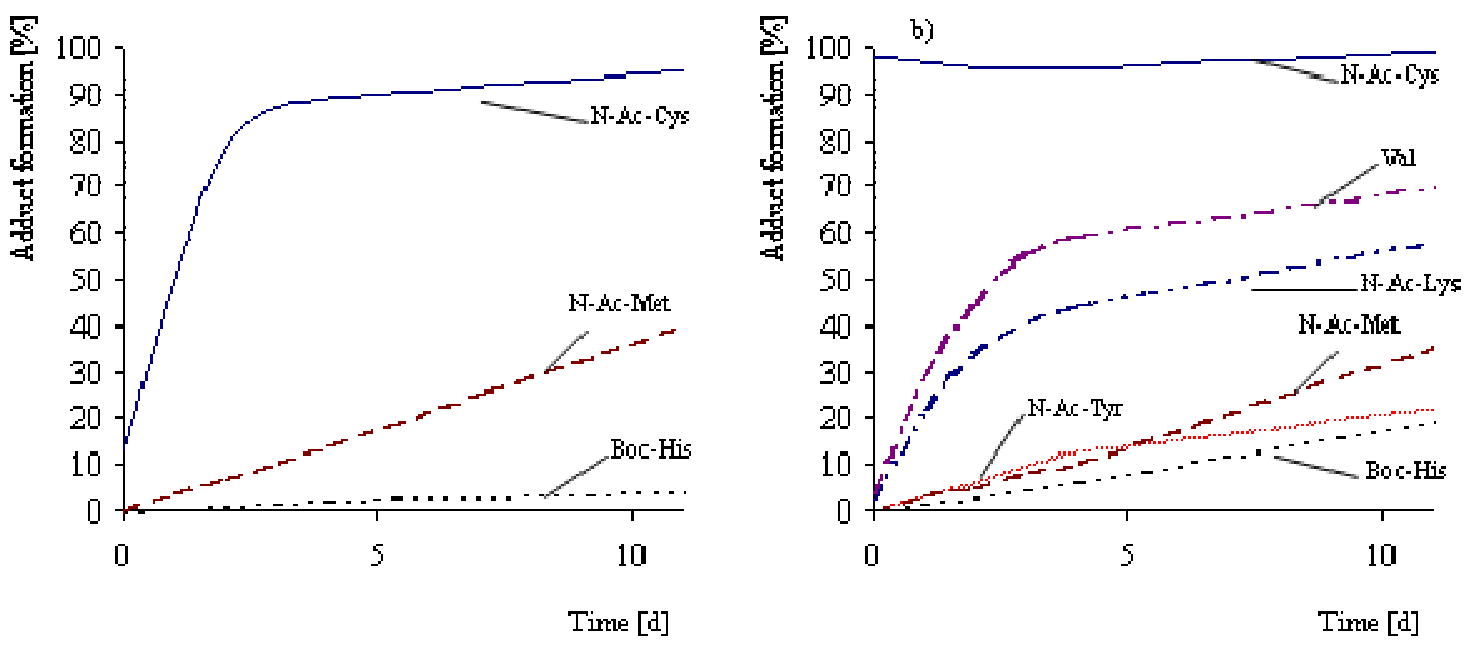

Fig. 2 Kinetics of adduct formation of BADGE $\cdot \mathrm{H}_{2} \mathrm{O}$ with proteinogenic amino acids at ambient temperature; a. $\mathrm{pH} \mathrm{7,} \mathrm{b.} \mathrm{pH} \mathrm{11;} \mathrm{conditions} \mathrm{cf.} \mathrm{experiments}$ 


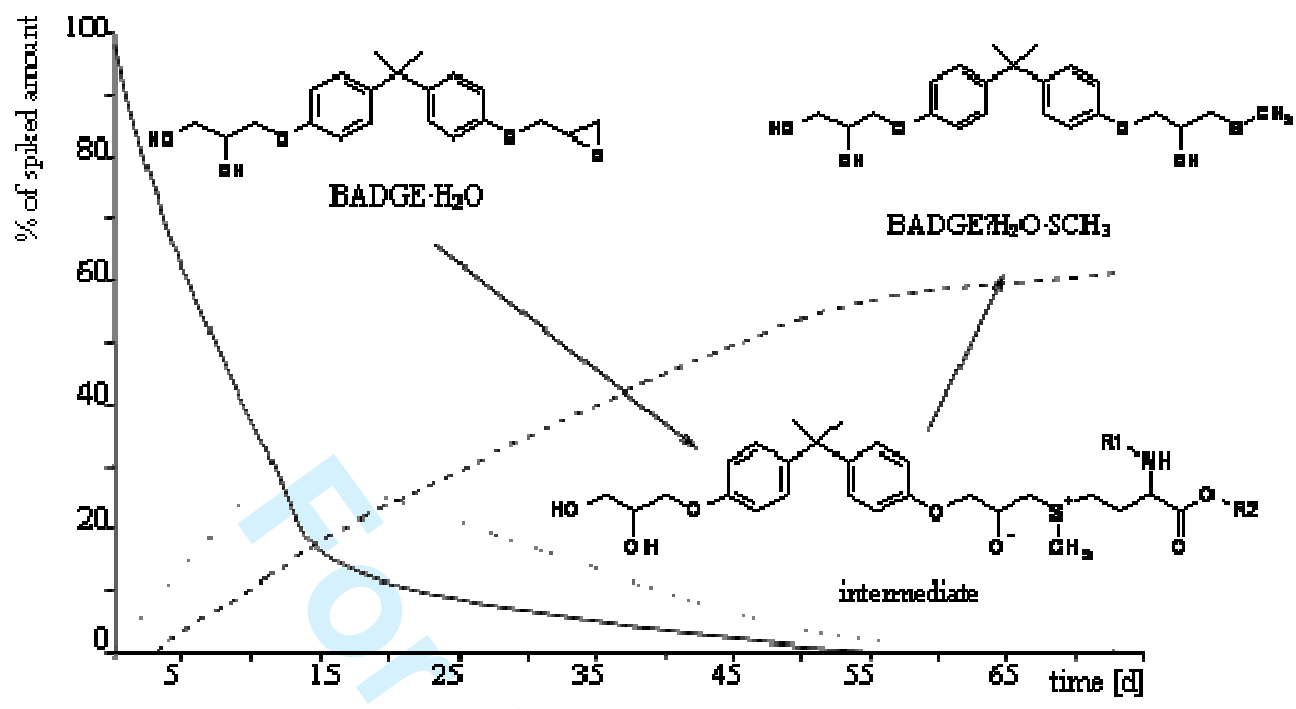

Fig. 3 Reaction of BADGE $\cdot \mathrm{H}_{2} \mathrm{O}$ with $\mathrm{N}$-Acetyl-methionine; ambient temperature; $\mathrm{pH}$ 11; conditions cf. Experimentals 


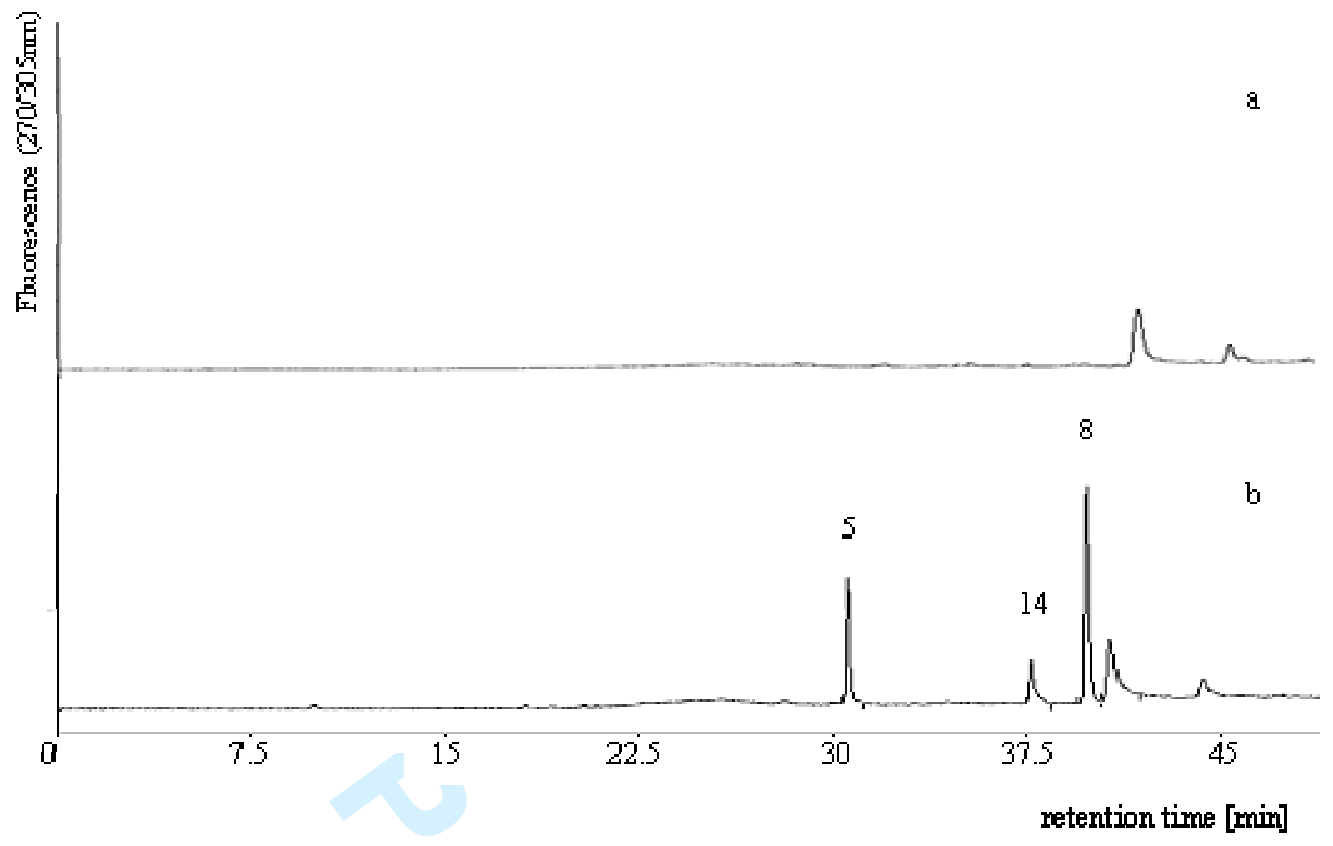

Fig. 4 Chromatogram of spiked tuna after sterilisation RP-HPLC/FLD, water (A) : acetonitrile/methanol (1/2; B), $0-40$ min $40-25 \% \mathrm{~A}, 5$ : BADGE $2 \mathrm{H}_{2} \mathrm{O}$; 8: BADHPE (IS); 14: BADGE $\cdot \mathrm{H}_{2} \mathrm{O} \cdot \mathrm{SCH}_{3}$; a: control sample, b: spiked with BADGE $\mathrm{H}_{2} \mathrm{O} 10 \mathrm{mg} / \mathrm{kg}$ 


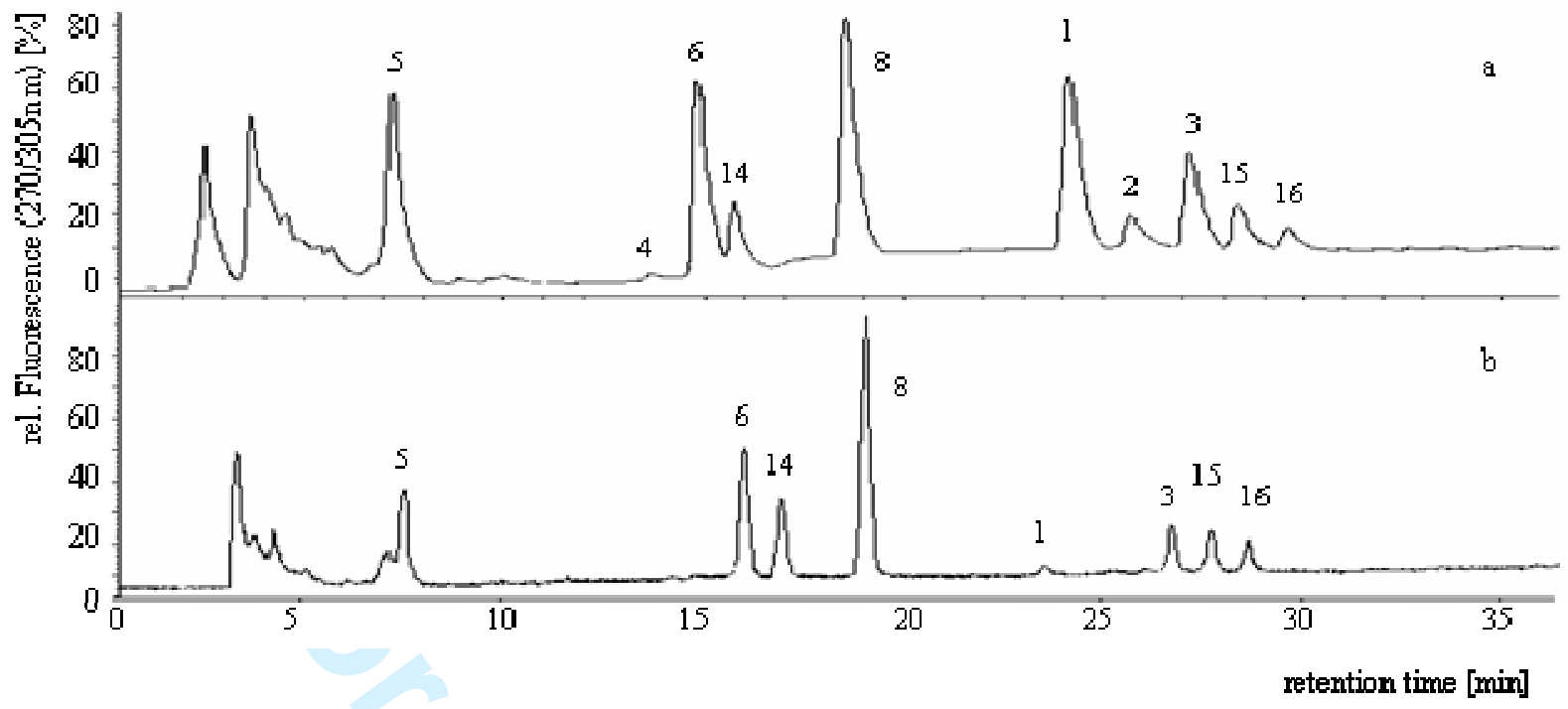

Fig. 5 BADGE derivatives in semolina pudding from BADGE containing packagings RP-HPLC/FLD, water (A) : acetonitrile/methanol (1/2; B), $0-40$ min $40-25 \% \mathrm{~A}, 1$ : BADGE; 2: BADGE·HCl; 3: BADGE $2 \mathrm{HCl}$; : $\mathrm{BADGE} \cdot \mathrm{H}_{2} \mathrm{O} ; 5: \mathrm{BADGE}_{2} \mathrm{H}_{2} \mathrm{O} ; 6$ : $\mathrm{BADGE} \cdot \mathrm{HCl} \cdot \mathrm{H}_{2} \mathrm{O} ; 8$ : BADHPE (IS); 14: BADGE $\cdot \mathrm{H}_{2} \mathrm{O} \cdot \mathrm{SCH}_{3} ; 15: \mathrm{BADGE} \cdot \mathrm{HCl} \cdot \mathrm{SCH}_{3}$; 16: $\mathrm{BADGE} \cdot 2 \mathrm{SCH}_{3}$ a: initial analysis, b: analysis after storage 